\title{
THE CLASSICAL JOURNAL
}

Volume 115, Nos. 3-4

ARTICLES (ESSAYS IN HONOR OF JOHN F. MILLER)

JenNy STRAuSS Clay AND ANKE WALTER: Introduction

JAMES M. MAY: Deorum beneficio rei publicae procreatus: Cicero's

Panegyrical Portrait of Octavianus

A.J.WOODMAN: Horace's "Roman Odes"

Sergio CaSAli: The Kings of the Laurentes: Contradictions and Points of View in Virgil's Aeneid

Julia HejDuk: Sacrificial Acrostics and the Fall of Great Cities in Virgil and Lucan

Megan Elena Bowen: Patterns of Prayer in Ovid's Metamorphoses and

the Suppressed Rape of Lavinia

JOSEPH FARRELL: Ovidian Synchronisms

DeNIS FEENEY: Forma manet facti (Ov. Fast. 2.379): Aetiologies of Myth and Ritual in Ovid's Fastiand Metamorphoses

Carole E. NeWlandS: Ovid's Aristaeus ( Fast. 1.363-80)

ANKE Walter: Carmentis and the Poet: Deification and Exile in Ovid's Fasti

K. SARA MYERS: Divine Journeys: Geographical Catalogues in Ovid's Fasti 4

CHRISTOPHER NAPPA: Naming June: Cult, Intertextual Competition and Augustan Politics in Ovid's Fasti 6

Charles MCNelis: Bacchus, Hercules and Literary History in Statius' Achilleid

FORUM

CHristopher Bungard And Vivian Deno: "She Isn't Quiet Yet": Music, Medea and the Modern Classroom

Clara Hardy, Lisl WalSh, John Gruber-Miller, SANJAYA ThakUR AND ANGELA ZisKowSKi: "The Classics Tuning Project": Competencies, Value and Visibility of the Classics at Small Liberal Arts Colleges BOOK REVIEWS

Louise PraTT: Casey Dué, Achilles Unbound: Multiformity and Tradition in the Homeric Epics

KenNeth F. KitChell JR.: Paul T. Keyser and John S. Scarborough, eds., The Oxford Handbook of Science and Medicine in the Classical World

Ariana Traill: Arlene Holmes-Henderson, Steven Hunt and Mai Musié, eds., Forward with Classics: Classical Languages in Schools and Communities 
THE KINGS OF THE LAURENTES:

CONTRADICTIONS AND POINTS OF VIEW IN VIRGIL'S AENEID

\begin{abstract}
The genealogy of the kings of the Laurentes given by the narrator at Aen. 7.459 (Saturn-Picus-Faunus-Latinus) is at odds with the one suggested by the description of the statues of Picus' palace at 7.177-91, where we find the sequence Italus-SabinusSaturn-Janus-Picus. Both genealogies are then contradicted by Evander's account of the history of Latium at 8.313-36. These irreconcilable versions reflect the different political and cultural interests of the different characters involved (the "Varronian" narrator, the kings of the Laurentes themselves and King Evander).
\end{abstract}

\title{
Keywords: Virgil, Aeneid, contradictions, Evander, Latinus
}

I

three passages from Aeneid 7 and 8 we find outlined, or implied, three (incompatible, as we shall see) genealogies of the kings of the Laurentes. ${ }^{1}$ These passages are: the ancestry of Latinus as given by the narrator at 7.45-9, the statues in Picus' palace at 7.177-91 and the history of Latium given by Evander at $8.313-36$.

\section{The Ancestry of Latinus at Aen. 7.45-9}

My starting point is the genealogy of the kings of the Laurentes given by the narrator at Aen. 7.45-9, where the line comprises Saturn, Picus, Faunus and Latinus:

Rex arva Latinus et urbes

iam senior longa placidas in pace regebat.

hunc Fauno et nympha genitum Laurente Marica

accipimus; Fauno Picus pater, isque parentem

te, Saturne, refert, tu sanguinis ultimus auctor.

\footnotetext{
"I thank the editors for giving me the opportunity of expressing my heartfelt gratitude to John Miller, who for many years has been to me a friend, a mentor and a great help in difficult times. A version of this paper has in fact been given for the first time at the University of Virginia during my last visit to Charlottesville, in October 2018, and then at Milan (Cattolica) and Toronto. I wish to thank Luigi Galasso, Alison Keith and members of those audiences for their interesting questions and remarks.

${ }^{1}$ On Virgil's use of the ethnonym Laurens, see Horsfall (1987).
}

THE CLASSICAL JOURNAL 115.3-4 (2020) 283-301 
King Latinus, now old, ruled over lands and towns in the calm of a long peace. He was, we are told, the son of Faunus and Marica, a Laurentine nymph. Faunus' father was Picus, and he claims you, Saturn, for father; you are the ultimate source of the bloodline.

This genealogy was certainly Varronian, at least as far as regards the sequence Picus-Faunus-Latinus. ${ }^{2}$ The relevant passage is De gente populi Romani F27 Fraccaro (ap. Aug. CD 18.15), where the father of Picus is not Saturn, but Sterces (or Stercutius), a good farmer who discovered fertilization in agriculture and so became a god. ${ }^{3}$ The list, however, must predate Varro, since annalists who do predate him already refer to the ancient gods Saturn, Faunus and Picus as divinized human beings. ${ }^{4}$ In all probability, Varro manipulated a pre-existing list of the kings of the Laurentes, which presented the genealogy Saturn-Picus-Faunus-Latinus, denying that Saturn was Picus' father. ${ }^{5}$ On the other hand, the fact that at Rust. 3.1.5 he affirms that those who till the ground are the sole surviving descendants of "King Saturn" - further confirmation, if need be, of the existence of a preVarronian tradition in which Saturn was a divinized human king —indicates that Varro in different works gave contrasting and contradictory accounts of Saturn; in one of these accounts Saturn could have been viewed as a divinized mortal, and maybe even as the father of Picus. ${ }^{6}$

In any case, when Virgil says hunc Fauno et nympha genitum Laurente Marica / $\underline{\text { accipimus; }}$ Fauno Picus pater [sc. est], isque parentem / te, Saturne, refert, it

\footnotetext{
${ }^{2}$ See Horsfall (2000) on 7.47 and (2016) 83-4.

${ }^{3}$ That the main source of Augustine's De Civitate Dei 18 is Varro's De gente populi Romani is demonstrated by Kettner (1865) 38-78; Frick (1886) esp. 3-6 and 40-4 (on CD 18.15); Fraccaro (1907) esp. 23-8 and 57-9 (on CD18.15).

${ }^{4}$ Saturn: L. Cassius Hemina, FRHist 6 F10 (ap. Tert. Apol. 10.7, Nat. 2.12, Min. Fel. 23.9, Lact. Inst. 1.13.8); Faunus: DServ. on Verg. G. 1.10 Cincius et Cassius aiunt ab Evandro Faunum deum appellatum ("Cincius [L. Cincius Alimentus, FRHist2 F10] et Cassius [L. Cassius Hemina, FRHist 6 F10] say that Faunus was called a god by Evander"); Picus: pontificales libri ap. Serv. on Aen. 7.190 augur fuit (Picus) et domi habuit picum, per quem futura noscebat: quod pontificales indicant libri ("Picus was an augur, and he had at home a woodpecker (picus), through which he knew the future; so say the pontifical books").

${ }^{5}$ See Fraccaro (1907) 176-7. Contra, most unconvincingly, Wifstrand Schiebe (1997), passim, according to whom Saturn as father of Picus is a Virgilian invention (on Aug. CD18.15, see 158-9). On the treatment of Saturn as a god in Varro's Antiquitates rerum divinarum, see van Nuffelen (2010) 165-70.

${ }^{6}$ So the testimony of Lactantius, Div. inst. 1.13.8, who says that Varro not only considered Saturn to be a human, but also related res eius in Italia gestas ("the deeds he did in Italy"), usually viewed as a mere mistake (see e.g. Fraccaro (1907) 177 n. 1; Briscoe on Hemina, FRHist 6 F1d, in Cornell (2013) 3.160), should perhaps be considered with more caution.
} 
seems as if he were self-reflexively highlighting his own correction of Varro's choice of Sterces as Picus' father (or at least his own choice between Sterces and Saturn in different parts of Varro): Virgil suggests that the link Faunus-Latinus is a claim that the narrator "receives" from, presumably, Varro, ${ }^{7}$ and so, we might think, also the link Picus-Faunus, which is presented as an "objective" (i.e. Varronian?) fact; Saturn, instead, is the father Picus, understandably, chooses for himself over the scarcely appealing Sterces, reflecting the epic narrator's choice of omitting that less decorous name.

The Statues in Picus' Palace at Aen. 7.177-91

The genealogy given at Aen. 7.45-9 is at odds with the picture that emerges from the description of Picus' palace at 7.177-91, where we find among Latinus' ancestors the sequence Italus-Sabinus-Saturn-Janus, while special prominence is later given to Picus (Aen. 7.177-82, 187-91): ${ }^{8}$

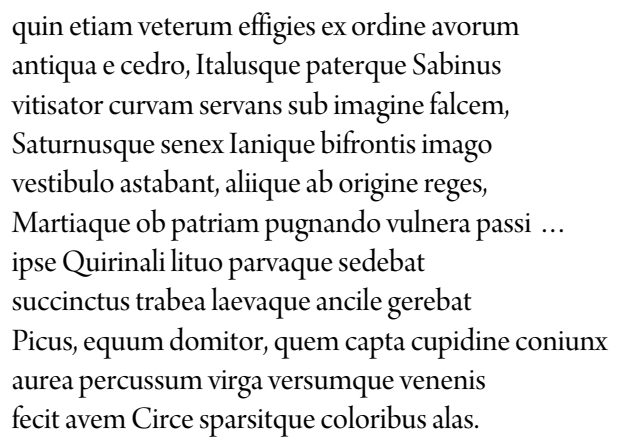

Here too there were statues of their forefathers of old, in order, made of ancient cedar-Italus and father Sabinus, sower of the vine, guarding in his image the curved sickle, and old Saturn, and the image of two-faced Janus - all standing in the hall; and the other kings from the beginning, and those who had suffered wounds of war, fighting for their fatherland ... Picus himself sat there, with the augural staff of Quirinus, and girt in a short robe, bearing the sacral shield in his left hand, the tamer of horses, whose wife, Circe, possessed by lust, struck with her golden wand and, transforming him with her potions, turned into a bird, and sprinkled colors on his wings.

\footnotetext{
${ }^{7}$ Horsfall (2000) ad loc " accipimus I I have read [probably] in Varro'."

${ }^{8}$ See Fordyce (1977) on 7.178, who sees here "clear evidence of lack of revision"; Rosivach (1980); Horsfall (2000) on 7.170-91 (with further references); Bleisch (2003) 102-3.
} 
According to the figurative programme of the Laurentis regia Pici (171) the "ancient ancestors" (veterum ... avorum) of (evidently) King Latinus are, "in order," Italus-Sabinus-Saturn-Janus; then "other kings from the beginning" (alii ... ab origine reges) are mentioned but not named, while the last statue described is that of Picus himself, apparently the builder of the palace. From the description of these statues there a crystal-clear picture of the genealogy of the kings of the Laurentes does not emerge. Let us consider, for now, the following problems: (i) Is the sequence Italus-Sabinus-Saturn-Janus a proper genealogy? That is, is Italus the father of Sabinus, Sabinus the father of Saturn, and so on? (ii) Who are the alii ... ab origine reges? Are they to be somehow inserted into the previous sequence or not? (iii) Why is Picus kept separated from the Italus-SabinusSaturn-Janus sequence and from the alii ... ab origine reges?

As to the first question, if we were to decide on the basis of this passage alone, it would seem natural to understand the sequence Italus-Sabinus-Saturn-Janus as a proper genealogy: Virgil is listing veterum effigies ex ordine avorum, the "statues of the ancient ancestors" - evidently, of Latinus and Picus - and he is doing this "in order" that is, "in visual and ('and therefore', even) chronological sequence." The very fact that Sabinus is called pater (178) is a further source of perplexity, since it seems to corroborate the impression that Virgil is referring here to some actual, though unclear, family relation between the characters in the list. ${ }^{10}$ As a matter of fact, however, not a single one of these supposed father-son relationships is elsewhere attested, and the situation would not become much simpler even if we were to think that there are missing links between the various kings mentioned as parts of the sequence. In fact, this sequence would remain problematic even if we were to think of those kings as listed in random order: the problem lies in their very consanguineity.

As many have seen starting with Servius, the phrase ab origine reges at 181 hints at the usual name of the Laurentes in the pre-Virgilian tradition, Aborigines, a name Virgil could not use in the nominative for metrical reasons. ${ }^{11}$ Since the Aborigines are the same as the Laurentes, it would seem reasonable to conclude

${ }^{9}$ Horsfall (2000) ad loc. Conington and Nettleship (1871) ad loc. state instead that "they are not in the order of succession," but the only reason for saying so is their wish to avoid the ensuing contradiction with 45-7. In their note on 181, however, they must admit that "this and what follows open a vista of previous history far more extensive than what is sketched in vv. 45 foll."

${ }^{10}$ See Horsfall (2000) ad loc., noticing that "the title has possibly a hint of 'ancestor', "even if in his opinion it "is more clearly to be understood as an all-purpose honorific ... for a remote and reverend figure."

${ }^{11}$ Serv. ad loc: AB ORIGINE <REGES> pro "Aboriginum reges" sed est metro prohibitus. 
that these alii ... reges are "other kings" of the Laurentes to be inserted into the same genealogy of which the Italus-Sabinus-Saturn-Janus sequence is a part. The alii ... reges could be imagined either as predating Italus, or as filling the gap between Janus and Picus, or both. What seems certain is that the genealogy of the kings of the Laurentes includes other unnamed kings besides Italus, Sabinus, Saturn, Janus and Picus. Among them, after all — but obviously afterPicus - there must be Faunus, who is not explicitly mentioned in this context, but whose status here as father of King Latinus cannot be called into question (cf. 81-2, 97, 103, where Faunus is repeatedly presented, both by the narrator and by Faunus himself, as Latinus' father). In any case, it is rather natural that Faunus does not appear in this list, since it is the palace of Picus, who predates Faunus, though of course Latinus might have added a statue of his father in the meantime.

As to Picus himself, an obvious answer to the fact that he is separated from the sequence Italus-Sabinus-Saturn-Janus by the unnamed alii ... ab origine reges is that Virgil wished to give him special prominence in his own palace, or to suggest that his statue (naturally enough) was in a separate area from the effigies ex ordine of his ancestors. Nonetheless, one cannot but notice the strangeness of the absence here of any particular emphasis on the relationship between Picus and Saturn, especially given the tendentiousness of the "claim" of Saturn as a father that we have seen in the narrator's words at $47-8$.

\section{Evander's Account of the History of Latium at 8.313-36}

At Aen. 8.313-36, Evander expounds to Aeneas his own view of the history of primitive Latium:

tum rex Evandrus Romanae conditor arcis:

"haec nemora indigenae Fauni Nymphaeque tenebant

gensque virum truncis et duro robore nata,

quis neque mos neque cultus erat, nec iungere tauros

aut componere opes norant aut parcere parto,

sed rami atque asper victu venatus alebat.

primus ab aetherio venit Saturnus Olympo

arma Iovis fugiens et regnis exsul ademptis.

is genus indocile ac dispersum montibus altis

composuit legesque dedit, Latiumque vocari

maluit, his quoniam latuisset tutus in oris.

aurea quae perhibent illo sub rege fuere

saecula: sic placida populos in pace regebat,

deterior donec paulatim ac decolor aetas 
et belli rabies et amor successit habendi. tum manus Ausonia et gentes venere Sicanae, saepius et nomen posuit Saturnia tellus; tum reges asperque immani corpore Thybris,

a quo post Itali fluvium cognomine Thybrim

diximus; amisit verum vetus Albula nomen.

me pulsum patria pelagique extrema sequentem

Fortuna omnipotens et ineluctabile fatum

his posuere locis, matrisque egere tremenda

Carmentis nymphae monita et deus auctor Apollo."

Then King Evander, founder of Rome's citadel: "These woods used to be the home of indigenous Fauns and Nymphs, and of a race of men birthed from trunks of trees and hard oak. They had no rules of conduct nor civilization, and did not know how to yoke oxen, gather wealth or husband what they garnered, but tree-branches and the harsh diet of huntsmen nurtured them. The first to arrive among them was Saturn, from heavenly Olympus, fleeing from Jupiter's weapons and exiled from his lost kingdom. He brought together this unruly people, scattered through the mountains, and gave them laws, and decided that the land be called Latium, since he had been safe in hiding within its borders. Under his reign occurred what tradition call the Golden Centuries: in such a calm peace he ruled over peoples. But little by little a worse and discolored age took their place, together with the rage of war and the lust for possessions. Then the Ausonian host arrived and Sicanian peoples, and too often the land of Saturn lost its name. Then kings came, and among them violent Thybris with giant bulk, from whose name we Italians have since called our river Thybris; thus ancient Albula lost its true name. Myself, expelled from my fatherland and seeking the ends of the ocean, all-powerful Fortune and unavoidable Fate set here in this place, where drove me the terrible warnings of the nymph Carmentis, my mother, and the authority of the god Apollo."

According to Evander's account, the indigenous dwellers were contemporary with Fauns and Nymphs, were born from trees, and did not know any civilization; when Saturn arrived from Olympus in flight from Jupiter, he settled them in cities and gave them laws; his reign was what men call the Golden Age. Afterwards, a worse age of war and greed took its place. Various other peoples invaded Latium, including Ausonians and Sicani, so that the land of Saturn changed its name many times. Subsequently there were kings, among them fierce Thybris with giant bulk, 
from whose name the Italians have since called the river Tiber. Then, most recently, Evander himself with his Arcadians. ${ }^{12}$

The presence of Saturn in Evander's account necessarily means that his history of the region must at the very least significantly overlap with the two previous genealogies, since both of them include Saturn as a protagonist. But how can Evander's account be reconciled with what the narrator says of Latinus' genealogy at 7.45-9 and with the genealogy suggested by the description of the statues in Picus' palace at 7.177-91? Of course it cannot. The remainder of this article will be devoted to highlighting the contradictions between these three different versions of the history of the royal family of Laurentes.

\section{Janus and Saturn}

The genealogy of Latinus as given by the "Varronian" narrator at 7.45-9 is unequivocal: Saturn-Picus-Faunus-Latinus. According to the figurative programme of the regia Pici, instead, the ancestors of King Latinus are, "in order," Italus-Sabinus-Saturn-Janus-( ... )-Picus. The only characters who appear in both lists are Saturn and Picus (but, as we have seen, Faunus is surely implied in the second list). The description of the statues of Picus' palace adds Italus and Sabinus before Saturn, and includes Janus, a figure who, in the part of the preVirgilian tradition that we can be certain about, is never attested as a king of the Laurentes. As we have already said, the most natural way of reading the sequence Italus-Sabinus-Saturn-Janus-(...)-Picus at 7.177-91 would be that of considering each king the father of the following one - but, if true, that would be, at the same time, bizarre to the point of grotesque: never, not only in the preVirgilian tradition, but also in the post-Virgilian one, is Saturn seen as the father of Janus. Rather, the mention in the same line of Saturn and Janus sounds very much like a hint at the story of how Janus welcomed the exiled Saturn in Italy and divided his reign with him; each of them founded for himself the cities of, respectively, Janiculum and Saturnia on the site of future Rome, a story that Evander implicitly refers to at $8.357-8$ :

hanc Ianus pater, hanc Saturnus condidit arcem; Ianiculum huic, illi fuerat Saturnia nomen.

This fortress was built by father Janus, that by Saturn; this was called Janiculum, that Saturnia.

\footnotetext{
there.

${ }^{12}$ See further Casali (2020) 149-61. In the following, I develop some ideas already sketched
} 
So, it is difficult not to read lines 7.180-1 as referring (with a sort of hysteron proteron, since we would have expected Janus to precede Saturn, as it happens at 8.357 ) to Janus/Saturn as the (supposedly) famous couple of co-rulers, and it is therefore rather easy to forget about the bizarre idea of Saturn as Janus' father (or ancestor) - in spite of the apparent literal inclusion of Janus among Latinus' avi. So, also in the genealogy suggested by the description of the statues in Picus' palace Saturn might be implicitly imagined as Picus' father, as in the genealogy of 7.45-9. This, after all, would cohere with the presentation of Saturn as the father Picus claims for himself at 7.48-9.

The presence of a reference to the story of Janus' and Saturn's joint rule in the genealogy suggested by the statues of Picus' palace, however, causes further problems. How can Janus and Saturn be both kings of the Laurentes and the founders and of course kings of, respectively, Janiculum and Saturnia on the site of future Rome? We could think of Janus and Saturn as kings of the Laurentes while living on the site of the future Rome; though not strictly impossible (and there are post-Virgilian lists of the kings of the Laurentes in which the sequence is JanusSaturn-Picus-Faunus), ${ }^{13}$ in the picture drawn by Virgil this would be strange and difficult; for example, if Saturn and Janus reigned as kings of the Laurentes while living on the site of future Rome, why at a certain point did their successors leave that place to move to the site of Latinus' city (at least since Picus)? In fact, nothing in Book 7 leads us to believe that Saturn or Janus ever lived and reigned on the site of future Rome. ${ }^{14}$

But there is a problem: we have referred to the story of Janus welcoming Saturn, which is especially famous for Ovid's treatment of it at Fasti 1.229-48, but as a matter of fact we do not have certain testimonies of this story before Virgil. We do have, however, indications that lead us to believe that such a story was indeed pre-

\footnotetext{
${ }^{13}$ See e.g. Hier. Chron. p. 62 b Helm: ante Aenean Ianus Saturnus Picus Faunus Latinus in Italia regnaverunt annis circiter $C L$ ("before Aeneas Janus, Saturn, Picus, Faunus, Latinus reigned in Italy for about 150 years").

${ }^{14}$ Not that the chronology of Latinus' city is particularly clear. Lines 7.59-62 suggest that Latinus had founded a new city, but later we discover that a Laurentis regia Pici, apparently something different from Latinus' arces, already existed in Latinus' city (170-6). Furthermore, this regia is characterized as venerably old $(169,172,173-4)$ — quite strangely if the palace had been built by Picus himself (as the phrase Laurentis regia Pici would suggest), who after all was only Latinus' grandfather. Maybe the venerable antiquity of their palace/temple is just an image that the Laurentine kings want to transmit to their visitors and to their own people, quite independently from the actual age of the building itself.
} 
Virgilian. Overhastily, both Eden and Fordyce, on 8.357-8, among others, ${ }^{15}$ attribute to Varro the story as narrated by Augustine ( $C D 7.4$ ), according to whom "Janus kindly welcomed Saturn when he was fleeing; he divided his kingdom with him, so that each of them also founded a city for himself, the one Janiculum, and the other Saturnia." 16 This story might go back to Varro and, before him, to Hemina (FRHist 6 F1), according to whom Saturn was human, ${ }^{17}$ but is surely attested, in some version, only since the slightly post-Virgilian Hyginus (FRHist 63 F10) and his source Protarchus of Tralles, of uncertain date (ap. Macr. Sat. 1.7.19-21), where it is not clear how much information is to be attributed to Hyginus/Protarchus. In Macrobius' account, Janus, a native inhabitant of Latium, after having shared for a while his kingship with the mysterious Camesis, and after having founded the city of Janiculum, received Saturn as his guest; from him Janus learned the art of the agriculture, and as a reward he associated with him in the kingdom. ${ }^{18}$

It seems highly unlikely that Virgil wrote $8.357-8$ without presupposing some earlier sources which somehow related a similar story. ${ }^{19}$ Such an elliptical reference to Janus and Saturn as founders of the twin cities of Janiculum and Saturnia cannot be the first attestation of the story of Janus and Saturn; otherwise, these two lines would have sounded cryptic and excessively disorientating to any reader. It is clear that the reader must have known something about the relationship of Janus with Saturn, and something on their foundation of their twin cities. The fact that a story about Janus' and Saturn's sharing of the kingdom, with the foundation of Janiculum and Saturnia, is in fact strongly attested, appearing

${ }^{15}$ Eden (1975) and Fordyce (1977).

${ }^{16}$ See Horsfall (2000) on 7.180: "The double association of Janus with both Janiculum (8.357, Ov. F. 1.245f. with Bömer's n.), and with Saturn is not securely Varronian (Aug. CD. 7.4 is not specific; Fordyce on 8.357f. is optimistic)." So already Agahd (1898) 54 n. 1.

${ }^{17}$ See the testimonies above n. 4. Minucius (23.10-12) goes on to recount an euhemeristic version of the story of Janus and Saturn, in which the latter was a fugitive from Crete, who, fearing the cruelty of his son, came to Italy to be welcomed by Janus, taught the uncivilized inhabitants of Latium many arts, and gave the region, his hiding-place, its name (from latere); memory of Janus and Saturn is guaranteed by the twin cities of Saturnia and Janiculum. This account can possibly go back to Hemina; see Briscoe on Hemina (FRHist 6 F1 in Cornell (2013) 3.160); Santini (1995) 107-13 gives this for granted. Contra, the always hypercritical Wifstrand Schiebe (1997) 24-5.

${ }^{18}$ To Macrobius it is simply obvious that Aen. 8.357-8 refer not only to the foundation of the twin cities by Janus and Saturn, but also to their sharing of the kingship; cf. Sat. 1.2.23.

${ }^{19}$ See, however, Levick and Cornell on Hyginus (FRHist 63 F10 in Cornell (2013) 3.558), who are inclined to think that this tradition originates with Hyginus, the mysterious Protarchus of Tralles and Ovid. 
just a few years after the publication of the Aeneid, clearly suggests that Evander's reference to the remains of Janiculum and Saturnia presupposes an already consolidated tradition, with Hemina and Varro as two probable candidates for the authorship or transmission of the story of Janus and Saturn.

Now, the story of how Janus welcomed Saturn to Italy and ruled jointly with him, one founding the city of Janiculum, the other that of Saturnia, stands in clear contradiction with Evander's earlier account of the history of primitive Latium at 8.319-25, where it is obvious that no previous king welcomed Saturn, who found in Latium only a genus indocile ac dispersum montibus altis (8.321). ${ }^{20}$ Furthermore, the phrasing of 8.356 strongly suggests that the founders of Janiculum and Saturnia were mortals (reliquias veterumque ... monimenta virorum, "the relics and memorials of men of old"), in contrast with Evander's preceding presentation of Saturn as a god (8.319-20), but in accordance with the euhemerism usually presupposed by the story of Janus welcoming Saturn (even if in Ovid both will be explicitly gods). ${ }^{21}$

If the Aeneid presupposes the story of Janus and Saturn, as Virgil's hints at that story at 7.180-1 and 8.357-8 lead us to believe, there is a marked contradiction between 8.319-23 (Evander's account of the history of Latium), where there is no king Janus to welcome Saturn and divide his reign with him, and 8.357-8 (Evander's words to Aeneas during the tour of the site of future Rome), which on the contrary, in my view, do presuppose the story of Janus and Saturn. Evander contradicts himself: at 8.319-23 he follows (or invents) a different tradition from the one he alludes to at 8.357-8.

\section{The Genealogical "Imperialism" of Picus and Latinus: Italus and Sabinus}

The inclusion of Janus among the statues of the Laurentine kings is surprising, given the absence of any pre-Virgilian reference to Janus as one of those kings. But we must be careful to notice that such an inclusion is not an initiative undertaken by the narrator, or by "Virgil"; it is they, the kings of the Laurentes themselves, who want Janus among their own ancestors. If, as I believe, the story of Janus' and

\footnotetext{
${ }^{20}$ OGR 2.4-3.7 must be an attempt at harmonizing the story of Janus/Saturn with Evander's account, and cannot be a right explanation of Virgil's text. The similar information contained in Macr. Sat. 1.7.21 can also be due to Macrobius' (or possibly Hyginus') not really successful intention of conciliating the story of Janus/Saturn with Evander's account. On the other side, it is also possible that a civilizing activity of Saturn at his arrival in Italy was already present in the annalistic tradition, if it were true that Minucius 23.10-12 goes back to Hemina (see above, n. 17).

${ }^{21}$ Cf. Servius ad loc: MONVMENTA VIRORVM hoc sermone ostendit etiam Saturnum virum fuisse ("by saying monumenta uirorum he indicates that even Saturn had been a man").
} 
Saturn's shared kingdom is pre-Virgilian, we may suppose that Janus' presence in Picus' palace is based on this very story: given that Saturn is attested as a king of the Laurentes, a joint kinship Janus/Saturn is more than enough to co-opt Janus among the Laurentine kings, and evidently even among Latinus' avi, even if - as we have seen - the twin kingdoms of Janiculum and Saturnia on the site of the future Rome would be a rather strange location for the precedessors of Picus, Faunus and Latinus.

In any case, the "Varronian" narrator had eliminated Janus from his list of the Laurentine kings; while complicated by the metanarrative references to his own sources (accipimus = "I have read (in Varro)"; Picus ... parentem, te, Saturne, refert = Saturn as the father Picus "claims" for himself over Sterces), his genealogy is otherwise simple and linear, a sober enumeration of four generations of kings, who have all presumably lived in the same place for decades. The narrator introduces Latinus as the king of a peaceful and idyllic reign; he needs things to be simple and sober while approaching the characterization of the Latins he wants to trace at the beginning of Book 7. The Varronian solution was the most appropriate to use here (leaving of course apart the embarrassing Sterces). The statues in the palace of Picus, on the contrary, include Janus as an ancestor, or at least as a predecessor. Simplicity and sobriety are not the important things here: here we see the Latin version of their own genealogy — a genealogy which expands itself to appropriate "other" kings. For Picus or Latinus Janus was a prestigious character to include among their predecessors and could not be sacrificed in the name of brevity or clearness.

If Janus, given his (most probably pre-Virgilian) associations with Saturn, was a natural candidate to be included in the list of the Laurentine kings, the other two additions to the "Varronian" list of kings, Italus and Sabinus, are much more surprising, but their strange inclusion among Latinus' avican also be explained, at least partially, according to this perspective.

As to the former, we might notice that Italus (otherwise the eponym of all Italy: cf. $1.533=3.166$ ) was also known as a king of the Sicels (eponym of Italy: Thuc. 6.2.4), and as the father of Sicelus (Philistus, FGrHist 556 F46, ap. Dion. Hal. 1.22.3); so here one might imagine him as a king of those Siculi/Sicani Evander will mention at 8.328 (gentes venere Sicanae), as contemplated by Horsfall, who muses about the possibility that "V. still thinks of him as in some sense a king of those Siculi/Sicani who ended up in Latium. ${ }^{22}$ But this would be very far from

\footnotetext{
${ }^{22}$ Horsfall (2000) on 7.178.
} 
being a "solution" to the problem: the Siculi/Sicani cannot easily be counted among the ancestors of the kings of the Laurentes. What Picus/Latinus do is to appropriate a king of a different people - just in the sense that they take a king of the Siculi/Sicani and "transform" him into an ancestor of theirs. ${ }^{23}$

A similar observation can be made about Sabinus. The presence of Sabinus (otherwise the eponym of the Sabines) alludes to an etymology of Sabinus from sero/sevi (7.178-9) indirectly attested by Lyd. Mens. 1.5 (the name Sabinus etymologized as "one who sows and plants vine"), and which perhaps lies beneath the strange "Oenotrus king of the Sabines" of Varro (GRF F397, ap. Serv. Aen. 1.532), as suggested by Poucet and accepted by Horsfall. ${ }^{24}$ It also alludes to the Sabine origin of the Aborigines according to Varro. Once again, on the one hand, Virgil alludes to a tradition he discards, while, on the other, Picus/Latinus exploit this different tradition, in order to enrich their genealogy with resonant and important names.

Briquel proposes that the references to Italus and Sabinus at $177-82$ are due to Virgil's intention of widening the perspective to the whole of the peninsula, as is suggested by the mention of the general eponym Italus. ${ }^{25}$ This may well be true, indeed it is probable. That intention, however, is not to be attributed to "Virgil," but to the kings of the Laurentes themselves: we have a contrast here between the narrator's position, and the position of the kings, who forcefully include among their ancestors figures that refer to a vision of Latium much more expansive, in both time and space, than the one the narrator envisions earlier in Book 7. Rosivach observes that "this series of kings and heroes emphasizes war and victory, and hegemony in Italy (note the eponymous Italus and Sabinus). ${ }^{26}$ This is part of a different treatment of the contradiction between Latinus' two genealogies, centred on the well-known inconsistency between Latium as a land at the same time both peaceful and warlike. ${ }^{27}$ Nevertheless, it fits my own argument very well: this is how the Latin kings view and present themselves through the power of images. $^{28}$

\footnotetext{
${ }^{23}$ As we shall see, Evander's history of the waves of immigrants in Latium is incompatible with the view of the past of Latium endorsed in Book 7 by both the narrator and the Laurentine kings.

${ }^{24}$ Poucet (1963) 191-7 and Horsfall (2000) on 7.179.

${ }^{25}$ Briquel (2017) 77.

${ }^{26}$ Rosivach (1980) 150.

${ }^{27}$ Rosivach (1980) 151-2.

${ }^{28}$ On 12.164, where the Sun is said to be Latinus' avus, see Moorton (1988) 256-9. On the otherwise unknown King Dercennus at 11.849-51, see Horsfall (2003) ad loc. and (2016) 84. For King Thybris, see below.
} 
In other words, the point is that the narrative at 45-9 is focalized through the narrator, a follower of Varro, whereas at 177-91 the narrator refers to the images that are present in the regia Pici, and that therefore describe what Picus and/or Latinus think of (or want people to think of) their ancestors. The contradiction is between two different views of the genealogy of the kings of the Laurentes, that of the "Varronian" narrator and that of the last kings themselves.

The History of Primitive Latium and Evander's Myth-Making

Both the genealogy of the kings of the Laurentes in Aen. 7.45-9 and the list at $7.177-91$ stand in further contrast with the whole of Evander's account of the history of the populations of Latium as expounded at 8.313-36.

Evander's account of the history of Latium cannot possibly cohere with what we are told in Book 7 first by the "Varronian" narrator (45-9) and then, in a sense, by the kings of the Laurentes themselves (177-82, 187-91). First, there is the issue of autochthony. According to Evander, the first inhabitants of Latium were born from trees, and so indigenous, and contemporary with the equally indigenous Fauns and Nymphs. The Varronian narrator, at 7.45-9, does not specify if Saturn, in his view the first king of the Laurentes and founder of the royal line (7.49), was indigenous to the land. When he later relates the view of the kings themselves, however, he specifies that Saturn (this time, as we have seen, not the first king, but - if ex ordine has any meaning — a successor of Italus and father Sabinus, and in fact a grandson of Italus and a son of Sabinus, since Virgil in describing veterum effigies ... $\underline{\text { avorum }}$ ) is one of the ab origine reges (7.181), that is, as mentioned above, a king of the Aborigines. Now, the Aborigenes were not necessarily thought of as autochthonous to Latium; for example, they were probably presented as a Greek people in Cato's Origines (FRHist 5 F49), while according to Varro, as we have seen, they were indigenous to Sabina. Nevertheless, the phrase aliique $a b$ origine reges clearly implies that the kings listed at 7.177-82 were autochthonous to Latium, for it involves a play on the etymology of Aborigines from ab originethat is, the etymology used to explain the name by implying that the Aborigines are autochthonous to Latium. ${ }^{29}$ Saturn cannot be at the same time, as one of the $a b$ origine reges, an autochthonous king of the Laurentes, and, as Evander's Saturn/Cronus, an immigrant from Olympus. ${ }^{30}$ But even apart from the

\footnotetext{
${ }^{29}$ Cf. Dion. Hal. 1.10.1.

${ }^{30}$ In other words, Virgil maintains and splits between Book 7 and Book 8 an inconsistency which was inherent to the figure of Saturn: cf. Versnel (1994) 139 (not noticing the contradiction in Virgil):
} 
implications of ab origine reges, it is clear that the royal list at 7.177-82 inevitably contradicts Evander's idea of Saturn as an Olympian god who migrated to Latium: again, if $\mathrm{ex}$ ordine has any meaning, the royal sequence Italus-Sabinus-Saturn itself excludes the possibility that Saturn came to Latium as an immigrant god who found there a genus indocile ac dispersum montibus altis (8.321). According to the figurative programme of Picus' palace, Saturn is a king inserted into an already existing line of kings of the Aborigines/Laurentes, not the civilizer and first king of "an untamed people, dispersed through mountain heights."

The figure of Faunus, repeatedly presented by the narrator in Book 7 as Picus' son and Latinus' father (e.g. 7.48, 81-2, 102), is also difficult to harmonize with what Evander says in Book 8. In Book 7 Faunus is a god, or rather a divinized mortal: even as a king of the Laurentes, he obviously preserves characteristics of the god, as his prophecy at $81-106$ makes clear. ${ }^{31}$ In any case, he is a single, definite person. Evander, on the contrary, in his account of the history of primitive Latium, speaks of plural Fauni as the first, indigenous inhabitants of that land, contemporary with the Nymphs and with the people born from trees. Now, the co-presence of a single Faunus and a plurality of Fauns (the plural Fauniis attested since Enn. Ann. 207) is not per se surprising: the coexistence of a divine or divinized Faunus with plural Fauns may not be an easy thing to understand, but it is something inherent in the Roman way of thinking about those entities. ${ }^{32}$ However, what becomes verydifficult to understand is how we should explain the fact that according to the version of Book 7 Faunus is the grandson of Saturn, whereas according to Evander's version the Fauns would have inhabited Latium well before the very arrival of Saturn in that land. If Evander's plural Fauns are to be imagined as "creatures" of the Faunus of Book 7 (something that Montanari, for example, both accepts and finds "not surprising"), ${ }^{33}$ how can we explain the fact that he was still non-existent at the time of their presence on the soil of Latium?

Evander does not mention Faunus in his ethnographical lecture to Aeneas. During the tour of the site of the future Rome, however, he does mention Faunus' Greek counterpart, Pan: at 8.343-4 he shows to Aeneas gelida ... sub rupe Lupercal / Parrhasio dictum Panos de more Lycaei ("the Lupercal, so called by the

\footnotetext{
"On the one hand, Saturn was regarded as autochthonous and as belonging to the first stratum of Latin settlers [= Aen. 7]. Consequently, he was often regarded as the first king of Latium or even of Italy. On the other hand, he is generally depicted as an immigrant [= Aen. 8].”

${ }^{31}$ See Otto (1909) 2054.

${ }^{32}$ See Otto (1909) 2060, correcting Wissowa (1886-90) 1454.

${ }^{33}$ Montanari (1988) 687.
} 
Arcadian tradition of Pan Lycaeus"). Evander, that is, attributes to himself the introduction of the worship of the Arcadian Pan into the site of the future Rome, and specifically into the cave of the Lupercal, so named - in his view - after Pan Lycaeus. ${ }^{34}$ It is most natural to associate Evander's identification of the god of the Lupercal with Arcadian Pan with an identification of Pan with Faunus, who appears as the god of the Lupercal at least since the mid- $2^{\text {nd }}$ century BCE historian Acilius (FRHist 7 F1, ap. Plut. Rom. 21.9), whereas the idea that it was Evander who introduced "in Rome" the cult of Pan Lupercus might go back to Eratosthenes (mid- $3{ }^{\text {rd }}$ century BCE) ${ }^{35}$ In any case, "in the developed tradition it was agreed that the Lupercalia had been established in honour of Faunus by Evander." ${ }^{36}$ It would seem, then, that Evander has a very different notion of "Faunus" from that of the narrator of Book 7, since there is clearly no way to harmonize his view of Pan/Faunus as an Arcadian god, whose cult is relocated by himself in Latium, with the narrator's view of Faunus as an Italian divinized man, grandson of Saturn, son of Picus, and father of Latinus. Evander's Pan Lycaeus cannot be identified with Italian Faunus, and the only "rational" thing to do would be to think that the two are different characters. ${ }^{37}$

Similarly, and even more clearly, Evander's Saturn cannot be the same Saturn who is the great-grandfather of King Latinus in Book $7 .{ }^{38}$ Like Faunus, the Saturn too who is the father of Picus in Book 7 is best to be imagined as a sort of divinized mortal: while there is nothing to suggest that he is anything more than a man in the narrator's account at 7.48-9, he will appear as a god in Latinus' words to the Trojans at 7.202-4. Evander's Saturn, instead, is unmistakenly an Olympian god, Saturn/Cronus (8.319). More importantly, Evander's Saturn/Cronus cannot be

${ }^{34}$ Different will be the narrator's view in describing the shield of Aeneas: the phrasing of 8.630-4 clearly alludes to an association of Lupercal with lupa: see O'Hara (2017) 101-2 and also Casali (2010) 40.

${ }^{35}$ Eratosthenes(?), ap. Schol. Vet. ad Plat. Phaedr. 244B; the testimony of the scholium is accepted, among others, by Wiseman (1995) 3; for skepticism, see, however, Horsfall (2013) 130.

${ }^{36}$ Bispham and Cornell on Cincius (FRHist 2 F10 in Cornell (2013) 3.57).

${ }^{37}$ We cannot know how the relationship between Faunus and Arcadian Pan was treated by those annalists who attributed to Evander the deification of Faunus: see above n. 4.

${ }^{38}$ We do not have any exact precedent for the story of Saturn as presented by Evander here, but I agree with Horsfall (2000) on 7.180 that "the origin of this account is not Virgilian, but earlier, if not definitely securely annalistic"; most importantly, the story of a mortal Saturn's flight and hiding in Italy (probably including the etymology of Latium from latere) was contained in Ennius' Euhemerus F5 Vahlen = F9 Goldberg-Manuwald (ap. Lact. Diu. Inst. 1.14.10-12, where however nothing is said about a reign of Saturn in Italy); see Winiarczyk (2013) 118 n. 51; Virgil is clearly alluding to Ennius here, on which see Casali (2020) 156. 
Picus' father for obvious chronological reasons: the Saturn of Book 7 must have lived in the third generation before the Trojan War, whereas according to a normal chronology, for example the Argive one, the reign of Jupiter began, after Saturn's dethronement, more than twenty generations before the Trojan War. According to Wifstrand Schiebe, we should imagine that Saturn did come into Latium in a remote past, but that, being immortal, he would have reigned over Latium for centuries, before fathering Picus only three generations before the Trojan War. ${ }^{39}$ This is a most implausible "solution": in Evander's account there is evidently no continuity between Saturn's rule and the "kings" he mentions at 8.330, and who clearly allude to the more recent kings of the Laurentes (even if their representative there, Thybris, is not mentioned in Book 7-of course, a further complication), for in between we have the deterior ... ac decolor aetas, and a succession of different dominations over the region (8.328-9). This means that it is impossible to imagine that Evander thinks of Saturn as uninterruptedly reigning over Latium for centuries.

Not only is the idea of a continuous reign of Saturn over Latium impossible; it is also extremely implausible to think, with Dominique Briquel, that Evander's account presupposes a continuous bloodline from the Fauns, the Nymphs and the people born from trees of 8.313 , to the successive peoples who inhabit Latium after them, and even a continuous royal dynasty from Saturn to Latinus. According to Briquel, the accounts in Book 7 and that in Book 8 would be coherent (as "Virgil's" version of the history of Latium), because the Fauns and Nymphs would be the same people as the tree-born gens, and this people should be identified with the Aborigines. ${ }^{40}$ With the arrival of Saturn, these "Aborigines" would have taken the name of Latins, so that we could postulate the existence not only of a continuous Aboriginal/Latin bloodline from the first stage of the history of Latium (that of the Fauns/Nymphs/tree-born people) to present-day Latium, but also of a continuous Aboriginal/Latin royal dynasty from Saturn to King Latinus. This presents insurmountable difficulties. First of all, the Fauns and the Nymphs are clearly not the same people as the tree-born gens. Secondly, Evander does not say that this people took the name of "Latins" at Saturn's arrival (it is the region which took the name of Latium). Thirdly, and most importantly, we must face the same problem mentioned above - that is, in Evander's account there is clearly no continuity of leadership from the rule of Saturn over the tree-born gens to that of the reges of 8.330: in between the region has seen the arrival of other peoples

\footnotetext{
${ }^{39}$ Wifstrand Schiebe (1997) 25-6.

${ }^{40}$ Briquel (1992) 78-9.
} 
(including Ausones and Sicani), who not only inhabited it (something that, in theory, could even have left an Aboriginal/Latin dynasty untouched), but established their domination over it, as its repeated changes of name indicate (8.329). In other words, Saturn cannot be one of the reges of 8.330 .

Evander's account is then inconsistent both with the "Varronian" narrator's account of the genealogy of King Latinus at 7.45-9 and with that suggested by the statues of the Laurentine kings in Picus' palace at 7.177-82, 187-91. The very presence of two predecessors of Saturn, Italus and Sabinus, in the list which can be drawn from Virgil's description of the statues of Picus' palace is in itself contradictory both with the narrator's version at 7.45-9, where Saturn is called sanguinis ultimus auctor (7.49) and no king is mentioned before him, and, above all, with Evander's account, where the tree-born people that welcomes Saturn also has clearly no king to reign over them, as we have seen above in connection with the story of Janus' welcoming of Saturn. In Evander's account, Italus and Sabinus could be counted among the "kings" (tum reges, 8.330) who reigned in Latium during the deterior ... ac decolor aetas (8.326) and after the invasions of Ausones and Sicani. These "kings" clearly suggest the kings of the Aborigines, but the only one of them referred to by name, Thybris, is not mentioned elsewhere in the Aeneid, and goes to keep Dercennus company as a Laurentine king wholly ignored in Book 7 and elsewhere. ${ }^{41}$ The tradition, recorded by Evander, of a presence of Sicani in Latium might have suggested to Picus and Latinus the idea of including Italus among their predecessors, as we have seen above; but in the world constructed by the Laurentine kings it would not be possible that Italus actually was a king of those Sicani that Evander mentions at 8.328, because the two passages presuppose a very different history of ancient Latium; think only of the fact that in 7.177-82 Italus, the would-be "king of the Sicels/Sicani," lives two generations before Saturn, while Evander locates his Sicani long after the reign of Saturn.

Evander has been seen as the prototype of the manipulative and tendentious Greek historians who teach the Trojan/Romans about their own past, ${ }^{42}$ while the proto-Roman Aeneas, who hangs upon Evander's lips while the king recounts his version of the history of Latium (8.310-12), represents the attitude of the Roman historians themselves, ready to eagerly adopt the Greek approach to Italian ethnography. Evander magnifies the history of Latium, and transforms a divinized

\footnotetext{
${ }^{41}$ See above n. 28.

${ }^{42}$ Cf. Casali (2010) 37-40.
} 
man or a secondary god and king into Saturn-Cronus, who, fleeing from Jupiter, hides himself in Latium where he inaugurates the Golden Age. ${ }^{43}$

\section{Conclusion}

Between the various genealogies and the various reconstructions of the Italian past offered in Aen. 7 and 8 there are irreconcilable contradictions. One should not try to neutralize these contradictions, let alone explain them away by invoking the poem's incompleteness. These inconsistencies are motivated by the different points of view of the different characters of the poem: each of them have their own political and cultural interests in inventing and presenting a certain version of the past. ${ }^{44}$ It could be interesting to attempt to treat this fragmentation of points of view as a self-reflexive comment on Virgil's part on his own political and cultural partiality in inventing the traditions of Italy and Rome-but this would be the topic of another paper.

\section{University of Rome “Tor Vergata,”casali@uniroma2.it}

SERGio CASALI

\section{WORKS CITED}

Agahd, Reinhold. 1898. " M. Terenti Varronis Antiquitatum rerum divinarum libri I XIV XVXVI. In Jahrbücher für classische Philologie, Suppl. 24, pp. 1-220. Leipzig.

Bleisch, Pamela R. 2003. "The 'Regia' of Picus: Ekphrasis, Italian Identity, and Artistic Definition in Aeneid 7.152-93.” In Being There Together: Essays in Honor of Michael C.J. Putnam on the occasion of his seventieth birthday, edited by Philip Thibodeau and Harry Haskell, pp. 88-109. Afton, MN.

Briquel, Dominique. 1992. "Virgile et les Aborigènes.” REL70: 69-91.

_ _. 2017. "Les Aborigènes et l'ethnographie de l'Énéide." In Magno e Latio totaque Ausonia. Etnografia virgiliana e Italia augustea, edited by Stéphan Bourdin and Alessandro Pagliara, MEFRA 129.1: 65-84.

Casali, Sergio. 2010. "The Development of the Aeneas Legend." In A Companion to Vergil's Aeneid and Its Tradition, edited by Joseph Farrell and Michael Putnam, pp. 3751. Malden, MA.

_ . 2020. "Evander and the Invention of the Prehistory of Latium in Virgil's Aeneid." In Nos sumus Romani qui fuimus ante...: Memory of Ancient Italy, edited by Michel Aberson, Maria Cristina Biella, Massimiliano Di Fazio and Manuela Wullschleger, pp. 145-68. Bern.

\footnotetext{
${ }^{43}$ On Evander's myth-making, see also Secci (2013).

${ }^{44}$ For a clever treatment of other inconsistencies in the Aeneid, see O'Hara (2007) 77-103.
} 
Conington, John, and Henry Nettleship, eds. 1871. P. Vergili Maronis Opera. The Works of Virgil, with a Commentary. London.

Cornell, T.J., ed. 2013. The Fragments of the Roman Historians (FRHist). 3 vols. Oxford. Eden, P. T., ed. 1975. A Commentary on Virgil, Aeneid VIII. Leiden.

Fordyce, C. J., ed. 1977. P. Vergili Maronis Aeneidos libri VII-VIII, with a Commentary. Oxford.

Fraccaro, Plinio. 1907. Studi varroniani. De gente populi Romani libri IV.Padua.

Frick, Carl. 1886. Die Quellen Augustins im XVIII. Buche seiner Schrift de civitate dei. Höxter.

Horsfall, Nicholas. 1987. "Laurentes." Enc. Virg. 3: 141-4.

—_, ed. 2000. Virgil, Aeneid 7: A Commentary. Leiden.

—_, ed. 2003. Virgil, Aeneid 11: A Commentary. Leiden.

—_, ed. 2013. Virgil, Aeneid 6. A Commentary. Berlin.

—_. 2016. The Epic Distilled: Studies in the Composition of the Aeneid. Oxford.

Kettner, Hermann. 1865. Varronische Studien. Halle.

Montanari, Elio. 1988. “Saturno." Enc. Virg. 4: 685-8.

Moorton, Richard F. 1988. "The Genealogy of Latinus in the Aeneid." TAPA 118: 253-9.

O'Hara, James J. 2007. Inconsistency in Roman Epic: Studies in Catullus, Lucretius, Vergil, Ovid and Lucan. Cambridge.

——. 2017. True Names: Vergil and the Alexandrian Tradition of Etymological Wordplay. $2^{\text {nd }}$ ed. Ann Arbor, MI.

Otto, W.F. 1909. “Faunus.” RE6.2054-73.

Poucet, Jacques. 1963. "Les origines mythiques des Sabins à travers l'œuvre de Caton, de Cn. Gellius, de Varron, d'Hygin et de Strabon." In Études Étrusco-Italiques. Mélanges pour le 25e anniversaire de la chaire d'Étruscologie a I'Université de Louvain, pp. 155225. Louvain.

Rosivach, Vincent J. 1980. “Latinus' Genealogy and the Palace of Picus.” CQ30: 140-52.

Santini, Carlo. 1995. I frammenti di L. Cassio Emina. Introduzione, testo, traduzione e commento. Pisa.

Secci, Davide A. 2013. "Hercules, Cacus, and Evander's Myth-Making in Aeneid8." HSCP 107: 195-227.

van Nuffelen, Peter. 2010. "Varro's Divine Antiquities: Roman Religion as an Image of Truth.” CP105: 162-88.

Versnel, Henk S. 1994. "Saturnus and the Saturnalia." In Inconsistencies in Greek and Roman Religion II. Transition and Reversal in Myth and Ritual, 2nd ed, edited by Henk S. Versnel, pp. 136-227. Leiden.

Wifstrand Schiebe, Marianne. 1997. Vergil und die Tradition von den römischen Urkönigen. Stuttgart.

Winiarczyk, Marek. 2013. The 'Sacred History' of Euhemerus of Messene. Berlin.

Wiseman, Timothy Peter. 1995. "The God of the Lupercal." JRS 85: 1-22.

Wissowa, Georg. 1886-90. "Faunus." Roschers Lexicon 1.2: 1454-60. 